\title{
МІНЛИВІСТЬ ЛІНІЙНИХ ОЗНАК ЕКСТЕР'ЄРУ КОРІВ-ПЕРВІСТОК СУМСЬКОГО ВНУТРІШНЬОПОРОДНОГО ТИПУ УКРАЇНСЬКОӦ ЧОРНО-РЯБОЇ МОЛОЧНОЇ ПОРОДИ ЗА РІЗНИХ ВАРІАНТІВ ПІДБОРУ ГЕНЕАЛОГІЧНИХ ФОРМУВАНЬ
}

\author{
Хмельничий Леонтій Михайлович \\ доктор сільськогосподарських наук, професор \\ Сумський національний аграрний університет \\ ORCID: https://orcid.org/0000-0001-5175-1291 \\ E-mail: khmelnychy@ukr.net \\ Бондарчук Лариса Володимирівна \\ кандидат сільськогосподарських наук, доцент \\ Сумський національний аграрний університет \\ ORCID: https://orcid.org/0000-0003-1129-9848 \\ E-mail: bondlara10@gmail.com
}

В аспекті дослідження консолідації корів сумського внутрішньопородного типу української чорно-рябої молочної породи за екстер'єром було проведено оцінку корів-первісток за методикою лінійної класифікації. Актуальність питання полягало у вивченні впливу на будову тіла корів методів підбору бугаїв із використанням різних комбінацій генеалогічних поєднань. Відповідно до результатів лінійної класифікації потомства плідників батьківської лінії Валіанта, спостерігалася значна варіабельність за оцінкою групових ознак у межах оцінюваних комбінацій із материнськими лініями. Найкращим за характеристикою групових ознак екстер'єру, які характеризують молочний тип, виявилося потомство корівпервісток, отриманих від внутрішньолінійного підбору (84,2 бали) та кросів ліній Валіанта × С.Т. Рокіта (84,3 бали) та Валіанта × Хеневе $(84,0$ бали). Найгірше ознаки молочного типу були виражені у корів-первісток, отриманих у результаті кросів ліній Валіанта × Метта (82,2 бали), які з істотною різницею поступалися одноліткам, отриманих у варіантах внутрішньолінійного та міжлінійного підборів, відповідно на 2,0 та 1,1-2,1 бали ( $P<0,05-0,001)$. Варіабельність оцінок корів-первісток за груповими ознаками та ффінальною оцінкою у варіантах різних лінійних поєднань батьківської лінії Метта з материнськими Валіанта, С. Т. Рокіта, Монтфреча, Хеневе та Сюпріма суттєво відрізняються між собою та, особливо, від рівня оцінок потомства, отриманого від внутрішньо- та міжлінійного підбору голштинських плідників батьківської лінії Валіанта з материнськими Валіанта, С. Т. Рокіта та Хеневе. Загалом, кращі результати в системі 100бальної оцінки за груповими ознаками та фінальною оцінкою типу отримано у варіанті внутрішньолінійного підбору лінії Валіанта та за їі кросів з материнськими лініями, продовжувачами яких є бугаї-плідники голштинської породи. За оцінкою описових ознак спостерігалася істотна мінливість як у межах груп корів-первісток, отриманих від різних міжлінійних поєднань, так і в межах кожної оцінюваної групи з кращими показниками оцінок у варіантах підбору у яких використовувалися бугаї-плідники голштинської породи з батьківського та материнського боку. ліній.

Ключові слова: корови-первістки, українська чорно-ряба молочна порода, екстер'єрний тип, бугаї-плідники, крос

DOI: https://doi.org/10.32845/bsnau.lvst.2019.4.1

Основною формою племінної роботи в молочному скотарстві за чистопородного розведення є розведення за лініями. Лінія - базовий компонент майже усіх структурних рівнів породи: стада, заводського типу, генеалогічної групи, внутрішньопородного типу [30]. Розведення за лініями у селекції скотарства є одним із найпотужніших засобів генетичного удосконалення новостворених українських порід і типів молочної худоби [2]. Тривале внутрішньолінійне розведення оригінальних, особливо цінних у селекційному значенні, генеалогічних формувань, без застосування вимушених міжлінійних кросів, можливе лише за умови наявності у кожній із них трьох-чотирьох відгалужень. При цьому, щоб забезпечити упродовж чотирьох-шести поколінь їхній прогресивний розвиток, необхідно мати достатню кількість бугаїв-поліпшувачів [4].

Наукові дослідження неодноразово засвідчують ефективність як внутрішньолінійного розведення, так і кросу ліній при підборі бугаїв-плідників у заводських стадах [5, 14, 17, 38, 39, 41, 42, 43, 46]. Про селекційну користь внутрішньолінійного розведення свідчить тривала зоотехнічна практика. Структуризація породи на окремі лінії, що відрізняють- ся між собою за розвитком господарськи корисних ознак, дозволяє створити у їхніх межах тварин з досить високою спадковою стійкістю, обумовленою великою кількістю генів. Полімерія сприяє розвитку господарськи корисних ознак і збільшенню гомозиготності до того рівня, який не викликає інбредних депресії, зберігаючи в породі достатній рівень мінливості [2]. Крім цього, при удосконаленні порід і типів молочної худоби неможливо сконцентрувати в одній тварині всі цінні якості, якими характеризується порода. Тому упродовж селекційного процесу в окремих лініях накопичуються різні позитивні корисні ознаки, із яких складається структура породи, надаючи йй пластичність, необхідну для подальшого iї поліпшення. Лінія, у процесі подальшого свого розвитку, окрім розповсюдження спадкових ознак родоначальника, утримує і об'єднує з ним достоїнства інших тварин. При цьому відбувається перетворення цінних властивостей у групові не тільки одного родоначальника, але й кращих маток, з якими він парується [47]. Цей процес призводить до прогресу лінії, основною властивістю якої $є$ здатність у кожному наступному поколінні давати плідників, які за своїми якостями не поступаються їхнім родоначальникам, а іноді й

Вісник Сумського національного аграрного університету 
перевершує їх. Тому внутрішньолінійне розведення повинно забезпечувати генетичний прогрес, але за умови чіткого дотримання системи добору, підбору й оцінки тварин за племінною цінністю $[1,2,7,32]$.

3 метою збагачення виведених ліній, поряд з іншими методами племінної роботи застосовують кроси 3 іншими лініями і спорідненими групами. Вважається, що цінні якості однієї лінії, доповнюючи якості іншої або виправляючи характерні для неї недоліки, збагачують у своєму поєднанні спадковість отриманого потомства при міжлінійних кросах $[6,8,21]$.

Вдалий крос ліній за чистопородного розведення $є$ результатом виникнення гетерозису, який можна пояснити неподібністю статевих клітин обох батьків. Найбільш вдалі поєднання дають ті лінії, які значно відрізняються одна від одної (гетерогенне парування). Парування представників подібних за продуктивністю ліній (гомогенне) супроводжується поєднанням подібних статевих клітин, внаслідок чого посилюють зростання гомозиготності та вірогідність отримати негативний результат зростає. При плануванні міжлінійного підбору слід вивчати результати поєднання ліній і використовувати найкращі сполучення. Цей процес потребує випробування визначних систем підбору, тому що лінія в одних поєднаннях може дати добрі результати, в інших посередні та навіть погані [10, 18, 25, 30, 35].

За результатами проведених досліджень корів сумського внутрішньопородного типу української чорно-рябої молочної породи встановлені та підтверджені статистичною достовірністю закономірності впливу на рівень ознак молочної продуктивності різних варіантів підбору. За оцінкою корів підконтрольних стад, одержаних за внутрішньолінійних та міжлінійних підборах, встановлено, що найчастіше, серед оцінених варіантів, кращим за ознаками молочної продуктивності виявлялося потомство, одержане від міжлінійних кросів. Тому в системі лінійного розведення вмотивована доцільність проведення регулярного моніторингу з оцінки поєднуваності ліній у селекційному процесі розведення молочних порід і типів. Повторне застосування найбільш вдалих та відмова від малоефективних варіантів підбору буде сприяти нарощуванню генетичного потенціалу молочної продуктивності худоби створених українських порід [2, $18,38,43,46]$.

Значна кількість авторів своїми дослідженнями доводять, що використання міжлінійних кросів, як селекційного заходу, дозволяє розширити основу спадковості, збільшити мінливість господарськи корисних ознак та використати ефект внутрішньопородного гетерозису. Крім того, вони сприяють швидкому підвищенню продуктивності і поліпшенню інших господарськи корисних ознак тварин, у тому числі й ознак екстер'єру $[9,12,19,20,22,23,24,27,28,33,35$, 36].

Встановлено, що рівень оцінок за комплексні та описові ознаки лінійної класифікації корів українських молочних та інших порід залежить від лінійної належності $[3,11,23]$. Використання методу розведення за лініями, як ефективного заходу в системі селекції молочної худоби, можна значним чином обґрунтувати одержаними достовірними величинами коефіцієнтів сили впливу лінії батька на ознаки екстер'єрного типу потомства $(3,4-49,7 \%)[34,45]$.

Сумський внутрішньопородний тип української чорно-рябої молочної перебуває на етапі консолідації за типом, тому потребує ретельної оцінки племінної бази. У цьому аспекті актуальним питанням $€$ використання ефективних селекційних заходів, спрямованих на консолідацію тварин за екстер'єром. Задля цього проведення експериментальних досліджень у напрямку вивчення екстер'єрних ознак тварин з урахуванням їхньої генеалогії $€$ вмотивованим та актуальним.

Матеріали та методи досліджень. Матеріалами досліджень слугувала інформація 3 лінійної класифікації корів-первісток сумського внутрішньопородного типу української чорно-рябої молочної породи племінного заводу ПП "Буринське" Підліснівського відділення, що знаходиться у Сумському районі. Для проведення досліджень були відібрані групи корів, які отримані у результаті різних варіантів міжлінійного підбору. Зокрема досліджувались дочки бугаївплідників наступних ліній: Валіанта 1650414, Метта 1392858, Монтфреча 91779, С. Т. Рокіта 252803, Хеневе 1629391 та Сюпріма 333470.

Лінійна класифікація здійснювалась за методикою двох систем: 100-бальною та 9-бальною з лінійним описом 18 статей екстер'єру [16]. Згідно рекомендацій ICAR [26] оцінювали наступні описові ознаки: ріст (stature), ширина грудей (chest width), глибина тулуба (body depth), кутастість (angularity), нахил заду (rump angle), ширина заду (rump width), кут задніх кінцівок вид збоку, (rear legs set), постава задніх кінцівок вид ззаду (rear legs rear view), кут ратиць (foot angle), переднє прикріплення вимені (fore udder attachment), висота прикріплення вимені ззаду (rear udder height), центральна зв'язка (central ligament), глибина вимені (udder depth), розташування передніх дійок (front teat position), розташування задніх дійок (rear teat position), довжина дійок (teat length), переміщення, хода (locomotion) та вгодованість (body condition score). Експериментальні показники опрацьовували за формулами біометричної статистики, наведеними Е. К. Меркурьевой [15].

Результати досліджень. У табл. 1 наведені результати оцінки потомства бугаїв-плідників, отриманого за різних варіантів підбору у межах генеалогічних формувань оцінених за 100-бальною системою лінійної класифікації.

Перші п'ять груп корів-первісток $є$ потомством бугаївплідників заводської лінії Валіанта 1650414 - одна з яких отримана у результаті внутрішньолінійного підбору та чотири у результаті міжлінійних кросів з материнськими лініями Метта 1392858, Монтфреча 91779, С. Т. Рокіта 252803 та Хеневе 1629391. Варто відмітити, що Валіант $1650414 €$ сином родоначальника відомої у голштинській породі лінії Павні Фарм Арлінда Чіфа 1427381 (502027). Валіант 1650414 був занесений у список кращих бугаїв США і займав там третє місце. Від 852 його дочок було отримано в середньому по 8902 кг молока жирністю $3,58 \%$ із загальним виходом молочного жиру 319 кг. Дочірні нащадки цієї лінії відрізнялися чітко вираженим молочним типом: міцні з правильною поставою задні кінцівки, ратиці з високою задньою стінкою та міцним ратичним рогом; крижі довгі, широкі 3 оптимальним нахилом; ріст середній, але зустрічалися й високі тварини, спина рівна, прямий та міцний поперек.

Наступні п'ять груп корів-первісток $€$ потомками бугаїв-плідників лінії Метта 1392858, які отримані за використання кросу з материнськими лініями - Валіанта 1650414, С. Т. Рокіта 252803, Монтфреча 91779, Хеневе 1629391 та Сюпріма 333470.

Вісник Сумського національного аграрного університету 
Показники лінійної оцінки корів-первісток, отриманих за різних варіантів підбору

Таблиця 1

в межах генеалогічних фрормувань за 100-бальною системою, $x \pm$ S.E. (балів)

\begin{tabular}{|c|c|c|c|c|c|c|c|}
\hline \multirow{2}{*}{ Лінія батька } & \multirow{2}{*}{ Лінія матері } & \multirow{2}{*}{$n$} & \multicolumn{4}{|c|}{ Групові ознаки лінійної класифікації корів, які характеризують: } & \multirow{2}{*}{$\begin{array}{c}\text { Фінальна } \\
\text { оцінка типу }\end{array}$} \\
\hline & & & молочний тип & тулуб & кінцівки & вим'я & \\
\hline Валіанта & Валіанта & 24 & $84,2 \pm 0,21$ & $85,3 \pm 0,23$ & $82,2 \pm 0,42$ & $84,2 \pm 0,21$ & $83,8 \pm 0,11$ \\
\hline Валіанта & Метта & 18 & $82,2 \pm 0,33$ & $82,7 \pm 0,33$ & $82,3 \pm 0,53$ & $82,0 \pm 0,32$ & $82,2 \pm 0,23$ \\
\hline Валіанта & Монтфреча & 20 & $83,3 \pm 0,22$ & $83,0 \pm 0,27$ & $82,9 \pm 0,34$ & $82,2 \pm 0,23$ & $82,7 \pm 0,16$ \\
\hline Валіанта & С. Т. Рокіта & 18 & $84,3 \pm 0,29$ & $85,3 \pm 0,32$ & $83,4 \pm 0,47$ & $84,0 \pm 0,27$ & $84,2 \pm 0,26$ \\
\hline Валіанта & Хеневе & 24 & $84,0 \pm 0,23$ & $85,0 \pm 0,31$ & $83,7 \pm 0,29$ & $84,0 \pm 0,22$ & $84,1 \pm 0,23$ \\
\hline Метта & Валіанта & 16 & $82,0 \pm 0,25$ & $83,3 \pm 0,36$ & $81,5 \pm 0,38$ & $81,9 \pm 0,18$ & $82,1 \pm 0,19$ \\
\hline Метта & С. Т. Рокіта & 30 & $82,5 \pm 0,30$ & $83,7 \pm 0,21$ & $81,0 \pm 0,42$ & $81,5 \pm 0,25$ & $81,9 \pm 0,15$ \\
\hline Метта & Монтфрреча & 18 & $80,8 \pm 0,22$ & $82,3 \pm 0,33$ & $81,7 \pm 0,44$ & $80,8 \pm 0,22$ & $81,3 \pm 0,16$ \\
\hline Метта & Хеневе & 26 & $82,4 \pm 0,26$ & $83,8 \pm 0,22$ & $81,1 \pm 0,30$ & $82,2 \pm 0,16$ & $82,3 \pm 0,10$ \\
\hline Метта & Сюпріма & 21 & $82,0 \pm 0,21$ & $82,6 \pm 0,27$ & $81,0 \pm 0,32$ & $82,1 \pm 0,17$ & $82,2 \pm 0,12$ \\
\hline
\end{tabular}

За результатами лінійної класифрікації потомства бугаїв-плідників батьківської лінії Валіанта спостерігалася достовірна мінливість за оцінками групових ознак у межах оцінюваних поєднань з материнськими лініями. Кращим за групою ознак екстер'єру, які характеризують молочний тип, виявилося потомство корів-первісток, отриманих від внутрішньолінійного підбору (84,2 бала) та кросу ліній Валіанта $\times$ С. Т. Рокіта $(84,3$ бала) та Валіанта $\times$ Хеневе $(84,0$ бали).

Найгірше виражені ознаки молочного типу виявилось у корів-первісток, отриманих у результаті кросу ліній Валіанта × Метта (82,2 бала), які з достовірною різницею поступаються одноліткам, отриманих у варіантах внутрішньолінійного та міжлінійного підборів, відповідно на 2,0 та 1,1-2,1 бала $(\mathrm{P}<0,05-0,001)$.

За аналогічного порівняння оцінюваних груп корів міжлінійного кросу Валіанта × Метта за груповими ознаками, які характеризують розвиток тулуба, вимені та фінальною оцінкою типу, спостерігалася така ж закономірність, згідно з якою вони поступалися за рівнем оцінок з достовірною різницею, відповідно - на 2,3-2,6 бала ( $\mathrm{P}<0,001), 2,0-2,2$ $(P<0,001)$ та $1,6-2,0$ бали $(P<0,001)$ в усіх варіантах порівнянь за виключенням одноліток від кросу ліній Валіанта $\times$ Монтфрреча.

Про не досить вдале поєднання ліній Валіанта × Монтфреча свідчать показники лінійної оцінки їхнього дочірнього потомства. Тварини від цього підбору поступаються за оцінкою групових ознак молочного типу, тулуба, вимені та за фрінальною оцінкою в усіх варіантах порівнянь, за виключенням потомства ліній Валіанта × Метта, відповідно - на 0,7-1,0 бала ( $\mathrm{P}<0,05-0,01), 2,0-0,3$ ( $\mathrm{P}<0,001), 1,8-2,0$ $(\mathrm{P}<0,001)$ та $1,1-1,5$ бала $(P<0,001)$.

Нижчі показники оцінок у корів-первісток, отриманих від кросів ліній Валіанта × Метта та Валіанта × Монтфреча, можна пояснити походженням бугаїв-плідників з боку батьківської та материнської ліній. Батьківську лінію Валіанта представляють чистопородні плідники голштинської породи (Д.Капріс 401393, М.М.Топрейт 387335, Л.Брітеск 5464072), які мають вищі показники оцінки типу дочок за лінійною класифікацією, тоді як материнські лінії Метта та Монтфреча представлені бугаями української чорно-рябої молочної породи (Модний 1533, Фронт 1561, Арик 4838, Гіпноз 4542, Добряк 4624) із значно нижчими характеристиками екстер'єрного типу дочок.
Мінливість оцінок корів-первісток за груповими ознаками та фінальною оцінкою у варіантах різних лінійних поєднань батьківської лінії Метта з материнськими Валіанта, С. Т. Рокіта, Монтфрреча, Хеневе та Сюпріма суттєво відрізняються між собою та, особливо, від рівня оцінок потомства, отриманого від внутрішньо- та міжлінійного підбору голштинських плідників батьківської лінії Валіанта з материнськими Валіанта, С. Т. Рокіта та Хеневе.

Досить невдалим виявився підбір бугаїв-плідників української чорно-рябої молочної породи при кросі ліній Метта і Монтфреча. Потомство від цього підбору мало найнижчі оцінки за груповими ознаками, які характеризують молочний тип (80,8 бала) та вим'я (80,8 бала), що достовірно нижче у порівнянні з іншими групами, батьки яких з материнської лінії $є$ чистопородними голштинами, відповідно на 1,2-1,6 (P<0,001) та 0,7-1,4 бала $(P<0,05-0,001)$.

Отже, за результатами лінійної класифікації корівпервісток сумського внутрішньопородного типу української чорно-рябої молочної породи за різних варіантів підбору генеалогічних формувань встановлено, що кращі результати оцінки за груповими ознаками та фінальною оцінкою типу отримано у варіанті внутрішньолінійного підбору лінії Валіанта та при її кросі з материнськими лініями, продовжувачами яких є бугаї-плідники голштинської породи.

Поряд зі стобальною системою лінійної класиффікації, оцінка корів за екстер'єрним типом за використання 9бальної шкали дозволяє оцінити найважливіші як у функціональному, так і в селекційному значенні окремі описові статі будови тіла тварин.

Наведені у табл. 2 показники лінійної класиффікації корів-первісток, отриманих за різних варіантів підбору, оцінених за описовими ознаками 9-бальної шкали, відрізняються істотною мінливістю як у межах генеалогічних формувань, так і окремих оцінюваних ознак.

Найперша ознака - висота тварини, яка характеризує загальний її розвиток за проміром у крижах, характеризується мінливістю оцінок у межах 5,5-6,5 бала, що є загалом вище середнього показника у стаді та породі. Кращі оцінки отримали дочки бугаїв-плідників батьківської лінії Валіанта у всіх варіантах підбору з нею.

Ширина грудей також не відрізняється значною мінливістю і становить 5,0-6,2 бала з вищим показником у дочірнього потомства, отриманого при міжлінійному кросі Валіанта $\times$ Метта.

Вісник Сумського національного аграрного університету 
За наступною, досить важливою функціональною ознакою - глибиною тулуба, оцінювані групи тварин за різного міжлінійного підбору характеризуються високими оцінками 3 мінливістю 6,0-7,8 бала, що свідчить про його достатньо добрий розвиток. Різниця між крайніми варіантами становить 1,8 бала з високим ступенем достовірності
(P<0,001), що підтверджує спадковий вплив лінійної належності на розвиток ознак екстер'єру. Найвищі оцінки отримано у дочок бугаїв-плідників у варіантах внутрішньолінійного підбору Валіанта - Валіанта (7,8 бала) та міжлінійного Валіанта × С. Т. Рокіта (7,7 бала) і Валіанта × Хановера (7,5 бала).

Таблиця 2

Показники лінійної класифікації корів-первісток, отриманих за різних варіантів підбору в межах генеалогічних формувань, оцінених за описовими ознаками 9-бальної шкали, $x \pm S$.E. (балів)

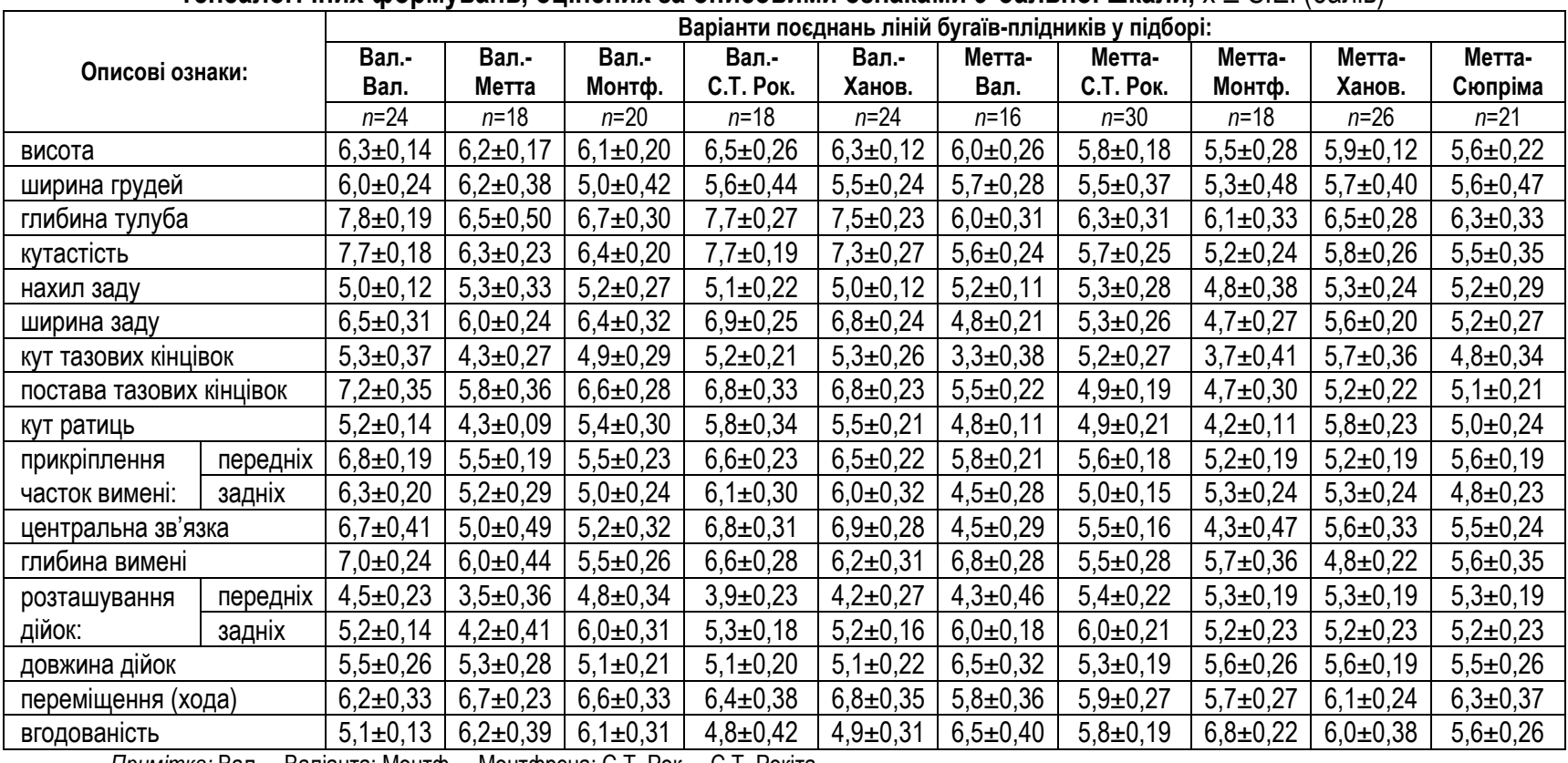
Примітка: Вал. - Валіанта; Монтф. - Монтфреча; С.Т. Рок. - С.Т. Рокіта

Потенційні можливості цих тварин щодо рівня молочної продуктивності значно вищі через добре розвинений у них шлунково-кишковий тракт, завдяки якому вони здатні з'їсти більшу кількість грубого корму і ефективно переробити його на молочну продукцію.

Для молочних корів характерна кутастість форм будови тіла. Досить важлива ознака молочності - це кут і ступінь відкритості ребер, відстань між ребрами, які мають бути плоскими. Ознаки молочності доповнюють чітко окреслені статі тварини, міцність, витонченість, ніжність та грація. Кутастість високо корелює з надоєм корів $[13,16,29,31,37]$. Мінливість оцінок за ознакою кутастості варіюе в широких межах - від 5,2 бала у потомства від кросу ліній Метта × Монтфрреча, до 7,7 бала - у дочок, отриманих від внутрішньолінійного підбору Валіанта - Валіанта (7,7 бала) та міжлінійного - Валіанта × С. Т. Рокіта (7,7 бала), що свідчить про високу потенційну молочність корів. Міжгрупова різниця становить за цією ознакою істотна та високодостовірна $-2,5$ бала $(P<0,001)$.

За ознакою нахилу заду мінливість оцінок варіює у незначних межах - 4,8-5,3 бала, з різницею між крайніми варіантами 0,5, яка не $є$ достовірною і свідчить про те, що серед оцінюваного поголів'я корів $€$ тварини як із дещо піднятими крижами, так і спущеними з незначним відхиленням від бажаного розвитку, яким характеризуються тварини, отримані від внутрішньолінійного підбору Валіанта Валіанта та міжлінійного - Валіанта $\times$ Хановера 3 середньою оцінкою п'ять балів.

Ширина заду, важлива лінійна ознака з огляду на проблему відтворення, оскільки у корів з широким задом відповідно ширші родові шляхи, що забезпечує легший перебіг отелення. Крім того ширина заду позитивно корелює 3 промірами вимені та 3 надоєм [13, 29, 31, 37, 40]. Мінливість за цією ознакою досить висока (4,7-6,9 бала) з достовірною різницею між крайніми варіантами 2,2 бала $(P<0,001)$. Кращий розвиток заду в ширину виявлено у корів-первісток, отриманих від поєднання ліній Валіанта $\times$ Хановера $(6,8$ бала) та Валіанта × С. Т Рокіта (6,9 бала).

Кут тазових кінцівок характеризує їхню міцність. Бажаний вираз даної лінійної ознаки характеризується оптимально величиною кута у скакальному суглобі, на рівні 146$148^{\circ}$, що дорівнює бажаному розвитку статі з середньою оцінкою у п'ять балів [16]. Зменшення кута скакального суглоба (шаблистість) або збільшення (слоновість) є недоліками статі. Серед корів, отриманих у варіанті кросу ліній Метта × Валіанта зустрічається істотний відсоток тварин зі слоновою поставою, про що свідчить оцінка 3,3 бала i, навпаки, оцінка 5,7 бала свідчить про наявність корів 3 шаблистістю, отриманих від поєднання лінй Метта × Монтфреча.

Досить високою мінливістю характеризувалися корови-первістки усіх піддослідних груп за оцінками описової ознаки «постава тазових кінцівок» - 4,7-7,2 бала, з достовірною різницею між крайніми варіантами 2,5 бала $(P<0,001)$. Найкращі оцінки виявлено у дочірнього потомства, отриманого від внутрішньолінійного підбору Валіанта - Валіанта $(7,2$ бала) та міжлінійного - Валіанта $\times$ С. Т. Рокіта $(6,8$ бала) і Валіанта × Хановера (6,8 бала).

За станом кута ратиць оцінка варіює з мінливістю у 
межах 4,2-5,8 бала та достовірною різницею між мінімальним та максимальним значенням 1,6 бала $(P<0,001)$. Мінливість цієї ознаки не залежить від варіанту підбору ліній.

Морфологічні описові ознаки вимені, що включені до лінійної класифікації корів, мають не лише продуктивну та технологічну цінність, але й від них значною мірою залежить здоров'я вимені та тривалість використання тварин молочної худоби, що підтверджують численні наукові дослідження $[3,37,44,45,48,49,51,53]$.

Лінійні ознаки, яким притаманні підтримуюча функція вимені на відповідній висоті, охороняючи його від травматичних та інфікуючих ризиків - прикріплення передніх і задніх часток вимені та центральна зв'язка, також відрізняються мінливістю, що є основною вимогою до лінійних ознак згідно з рекомендаціями ICAR.

За результатами лінійної оцінки краще прикріплення передніх часток вимені спостерігалося у корів, отриманих у варіантах внутрішньолінійного підбору Валіанта - Валіанта (6,8 бала) та міжлінійного - Валіанта × С. Т. Рокіта $(6,6$ бала) і Валіанта $\times$ Хановера (6,5 бала), тобто це ті варіанти підбору за яких як з батьківського, так і материнського боку використовувалися чистопородні голштинські бугаї-плідники. У решти груп корів, які були отримані у результаті міжлінійних підборів з використанням бугаїв-плідників української чорно-рябої молочної породи, рівень оцінки за розвиток цієї ознаки був меншим і становив у середньому 5,2-5,8 бала

Аналогічна закономірність спостерігалася за показниками оцінки ознак прикріплення задніх часток та розвитку центральної зв'язки вимені. Рівень оцінок свідчить про кращий їхній розвиток у корів, отриманих за внутрішньолінійного підбору Валіанта - Валіанта (6,3 та 6,7 бала) і міжлінійного - Валіанта × С. Т. Рокіта (6,1 і 6,8 бала) та Валіанта $\times$ Хановера (6,0 і 6,9 бала). Використання бугаїв лінії Метта у міжлінійних кросах з плідниками інших ліній не сприяли поліпшенню досить важливих у селекційному та технологічному значеннях морфологічних ознак вимені у їхнього потомства.

Цей висновок стосується також наступної технологі- чної ознаки - глибини вимені, оцінка за яку вища у варіантах поєднань тих ліній, продовжувачами яких є бугаї-плідники голштинської породи: внутрішньолінійного Валіанта Валіанта (7,0 балів) і міжлінійного - Валіанта × С. Т. Рокіта (6,6 бала) та Валіанта × Хановера (6,8 бала).

Мінливість у межах оцінюваних груп корів-первісток різних міжлінійних поєднань таких технологічних ознак вимені як розташування передніх та задніх дійок і їхня довжина варіюють відповідно 3,5-5,4 та 4,2-6,0 і 5,1-6,5 бала 3 достовірною різницею між крайніми варіантами відповідно 1,9 $(P<0,001), 1,8(P<0,001)$ та 1,4 бала $(P<0,001)$.

Ознака, яка характеризує рух тварин і за свідченням багатьох вчених значною мірою впливає на продуктивність та функціональну довговічність і залежить від оцінки кута тазових кінцівок і стану ратиць $[51,53]$ Оцінки корів за даною ознакою не відрізнялися значною мінливістю (5,7-6,7 бала), яка не зв'язана з поєднанням конкретних ліній, хоча різниця між крайніми варіантами в один бал достовірна при $\mathrm{P}<0,01$.

Висновки. 1. За результатами лінійної класифікації корів-первісток сумського внутрішньопородного типу української чорно-рябої молочної породи, отриманих за різних варіантів підбору генеалогічних формувань встановлено, що кращі результати в системі 100-бальної оцінки за груповими ознаками та фінальною оцінкою типу виявлено у варіанті внутрішньолінійного підбору заводської лінії Валіанта та при її кросі з материнськими лініями, продовжувачами яких $€$ бугаї-плідники голштинської породи.

2. За оцінкою описових ознак спостерігалася істотна мінливість як у межах груп корів-первісток, отриманих від різних міжлінійних поєднань, так і в межах кожної оцінюваної групи з кращими показниками оцінок у варіантах підбору у яких використовувалися бугаї-плідники голштинської породи з батьківського та материнського боку.

3. Для удосконалення корів молочної худоби за екстер'єрним типом важливо враховувати при підборі показники лінійної класифрікації бугаїв-плідників за типом їхніх дочок, відбираючи кращих продовжувачів ліній для використання у будь якому варіанту підбору.

\section{Список використаної літератури}

1. Буркат В.П., Ладика В.І. До питання створення молочного типу бурої худоби. Удосконалення племінних і продуктивних якостей популяції бурої худоби. Матеріали науково-виробничої конференції 25-27 червня 1996 року. К.: Асоціація "Україна", 1996. С. 3-5.

2. Буркат В.П., Полупан Ю.П. Розведення тварин за лініями: генезис понять і методів та сучасний селекційний контекст К.: Аграрна наука, 2004. 68 c.

3. Ефимова Л.В., Кулакова Т.В., Иванова О.В., Иванов Е.А. Взаимосвязь между признаками линейной оценки экстерьера и молочной продуктивностью коров. Вестник Новосибирского государственного аграрного университета, 2017. № 3 (44), C. 115-124.

4. Вінничук Д.Т. Структура породи великої рогатої худоби. Вісник сільськогосподарської науки, 1982. № 8, С. 33-38.

5. Воронина Е., Стрекозов Н., Амбрампальский Ф., Абылкасымов Д. Влияние вариантов подбора коров на их молочную продуктивность. Молочное и мясное скотоводство, 2007. №4, С. 8-10.

6. Гладій М.В., Полупан Ю.П., Базишина І.В., Безрутченко І.М., Полупан Н.Л. Вплив генетичних і паратипових чинників на господарськи корисні ознаки корів. Розведення і генетика тварин, 2014. № 48, С. 48-61.

7. Генетика, селекция и биотехнология в скотоводстве. Зубец М.В., Буркат В.П., Мельник Ю.Ф. [и др.]; под ред. М.В. Зубца, В.П. Бурката. К.: "БМТ", 1997. 722 с.

8. Димчук А.В. Молочна продуктивність корів подільського заводського типу української чорно-рябої молочної породи за різних варіантів підбору. Розведення і генетика тварин, 2008. Вип. 42, С. 55-62.

9. Зубець М.В., Полупан Ю.П. Методи і значення екстер'єрної оцінки молочної худоби. Нові методи селекції і відтворення високопродуктивних порід і типів тварин: Матеріали науково-виробничої конф. К., 1996. С. 74-75.

10. Игнатьева Н. Л. Продуктивные качества черно-пестрого скота в зависимости от линейной принадлежности. В сборнике: Пути реализации Федеральной научно-технической программы развития сельского хозяйства на 2017-2025 годы 
Материалы международной научно-практической конференции, посвященной 75-летию Курганской области. Под общей редакцией С. Ф. Сухановой. 2018. С. 458-462.

11. Кочук-Ященко О.А. Лінійна оцінка типу і молочна продуктивність корів української чорно-рябої молочної породи різної лінійної належності. Збірник наукових праць ВНАУ. Сучасні проблеми селекції, розведення та гігієни тварин, 2014. Вип. 1(83), T.2, С 139-149.

12. Кочук-Ященко О.А. Особливості екстер'єрного типу та молочної продуктивності корів-первісток української чорнорябої молочної породи за різних варіантів підбору. Вісник Сумського НАУ. Серія «Тваринництво», 2017. Вип. 5/1(31), С. 9096.

13. Ладика В. І., Хмельничий Л. М., Салогуб А. М. Сполучна мінливість статей екстер'єру корів з молочною продуктивністю. Білоцерківський національний аграрний університет. Технологія виробництва і переробки продукції тваринництва : зб. наук. пр. Біла Церква, 2010. Вип. 3(72), С. 9-11.

14. Левина Г., Сивкин Н., Петрова И. Пожизненный удой и долголетие коров. Молочное и мясное скотоводство, 2002. №6. C. 27-29.

15. Меркурьева Е. К. Генетические основы селекции в скотоводстве М.: Колос, 1977. 240 с.

16. Методика лінійної класифікації корів молочних і молочно-м'ясних порід за типом. Хмельничий Л.М., Ладика В.І., Полупан Ю.П., Салогуб А. М. Суми: ВВП “Мрія-1" ТОВ. 2008, 12 с.

17. Моисеев К.А., Павлова Т. В., Казаровец Н.В. Влияние генотипических фракторов на принадлежность хозяйственного использования и пожизненную молочную продуктивность коров в стаде РУП "Учхоз БГСХА". Розведення і генетика тварин: міжвідомчий тематичний науковий збірник. К., 2012. Вип. 46. С. 106-109.

18. Хмельничий Л. М., Салогуб А. М., Бондарчук В. М., Шевченко А. П. Молочна продуктивність корів одержаних при внутрішньолінійному підборі та міжлінійних кросах. Науково-теоретичний збірник Житомирського національного агроекологічного університету. ЖНАЕУ. 2015. №2 (52), Т. 3, С. 51-56.

19. Черняк Н.Г., Гончарук О.П., Козій В.І., Черняк С. В. Оцінка бугаїв-плідників за лінійною оцінкою типу дочок української чорно-рябої молочної породи. Вісник Сумського НАУ. Серія «Тваринництво», 2017. Вип. 5/1(31), С. $181-187$.

20. Пелехатий М., Кочук-Ященко О. Оцінка молочної продуктивності корів за екстер'єром. Тваринництво України, 2014. № 11, С. 5-9.

21. Пелехатий М.С., Кучер Д.М. Ефективність використання кросів ліній в заводському стаді української чорно-рябої молочної породи. Вісн. ЖНАЕУ, 2012. № 2 (31), Т 1, С. 141-151.

22. Полупан Ю.П. Екстер'єрні особливості первісток різних порід і поєднань. Розведення і генетика тварин. К.: Аграрна наука, 1999. Вип. 30, С. 10-16.

23. Полупан Ю.П. Лінійна оцінка первісток за типом при відтворному схрещуванні. Вісник Білоцерківського ДАУ. Біла Церква, 1997. Вип. 2 (1), С. 196-200.

24. Полупан Ю. П. Оцінка бугаїв за типом дочок. Вісник аграрної науки, 2000. № 5, C.45-49.

25. Полупан Ю.П. Суб'єктивні акценти з деяких питань генетичних основ селекції та породоутворення. Розведення і генетика тварин. К. : Аграрна наука, 2007. Вип. 41, С. 194-208.

26. Реєстрація ICAR. Довідник. Ладика В.І., Хмельничий Л. М, Буркат В. П., Рубан С.Ю. Суми: Сумський національний аграрний університет, 2010. 457 с.

27. Рубан Ю.Д. Теорія і практика розведення великої рогатої худоби за лініями. Розведення і генетика тварин, 2005. Вип. 38, С. 91-96.

28. Салогуб А.М., Хмельничий Л. М. Особливості лінійного розведення в селекційному поліпшенні продуктивності корів племінного стада. Збірник наукових праць Вінницького НАУ. Серія: Сільськогосподарські науки. Вінниця, 2010. Вип. 5, С. 129-133.

29. Салогуб А.М., Хмельничий Л. М. Особливості успадковуваності та сполучної мінливості ознак екстер'єру корів української червоно-рябої молочної породи. Збірник наукових праць Вінницького НАУ. Серія : Сільськогосподарські науки. Вінниця 2011, Вип. 8 (48), С. 59-62.

30. Селекція сільськогосподарських тварин. Гопка Б. М., Коваленко В. П., Мельник Ю. Ф., Найденко К. А., Нежлукченко Т. І., Пелих В. Г., Рудик І. А., Сахацький М. І., Трофименко О. Л., Угнівенко А. М., Цицюрський Л. М., Шеремета В. І. За заг. ред. Мельника Ю. Ф., Коваленка В. П. та Угнівенка А. М. К., 2007. 554 с.

31. Хмельничий Л.М., Салогуб А.М., Хмельничий С. Л., Лобода А. В. Співвідносна мінливість та успадковуваність лінійних ознак екстер'єру корів сумського внутрішньопородного типу української чорно-рябої молочної породи. Вісник Сумського національного аграрного університету. Серія «Тваринництво», 2018. Вип. 2 (34), С. 92-96.

32. Ставецька Р.В., Рудик І.А. Динаміка розвитку ліній молочної худоби. Збірник наукових праць. Серія "Технологія виробництва і переробки продукції тваринництва". Кам'янець-Подільський, 2010. Вип. 18, С.197-200.

33. Усова Т. Сочетаемость генеалогических групп и линий у айрширского скота. Молочное и мясное скотоводство, 1999. № 7, С. 21-23.

34. Хмельничий Л.М., Вечорка В. В. Вплив спадкових чинників на екстер'єрний тип корів української чорно-рябої молочної породи. Розведення та селекція тварин: досягнення, проблеми, перспективи: збірник наукових праць міжнар. наук.практ. конф., 20 квітня 2018 р. Житомир: Полісся, 2018. С. 105-110.

35. Хмельничий Л.М., Салогуб А М. Ефективність поєднання генеалогічних формувань в селекції молочної худоби. Збірник наукових праць Подільського держ. аграрно-технічного університету. Серія "Технологія виробництва і переробки продукції тваринництва". Кам'янець-Подільський, 2012. Вип. 20, С. 285-287.

Вісник Сумського національного аграрного університету 
36. Хмельничий Л.М., Лобода В.П. Селекційне значення ліній та бугаїв-плідників у формуванні ознак молочної продуктивності їхнього потомства. Вісник Житомирського національного агроекологічного університету. Житомир, 2013. №1, Т. 2 (35), C. 40-45.

37. Хмельничий Л.М. Ефективність використання методики лінійної класифікації для оцінки бугаїв-плідників за екстер'єрним типом їхніх дочок у стаді з розведення української червоно-рябої молочної породи. Вісник Сумського національного аграрного університету. Серія «Тваринництво», 2017. Вип. 7(33), С. 17-24.

38. Хмельничий Л.М., Вечорка В.В.Ефективність внутрішньолінійного розведення та поєднуваності ліній в селекції голштинської худоби. Вісник Сумського НАУ. Наук. журнал. Серія “Тваринництво”, 2010. Вип. 12 (18), С. 149-153.

39. Хмельничий Л.М., Вечорка В. В. Ефективність впливу генеалогічних формувань на показники довголіття та довічної продуктивності корів української червоно-рябої молочної породи. Вісник Сумського НАУ. Серія «Тваринництво», 2016. Вип. 1 (29). С. 3-10.

40. Хмельничий Л.М., Супрун І.О. Оцінка корів-первісток українських червоно- та чорно-рябої молочних порід за ємністю вимені. Збірник наукових праць Луганського НАУ. Серія «Сільськогосподарські науки». Луганськ. «Елтон-2», 2010. № 21, C. $187-188$

41. Хмельничий Л.М., Вечорка В. В. Оцінка потомства ліній та бугаїв-плідників голштинської породи канадської селекції за ознаками довічної продуктивності. Науковий вісник національного університету біоресурсів і природокористування України. Серія: Технологія виробництва і переробки продукції тваринництва. К., 2014. Вип. 202, С. 83-90.

42. Хмельничий Л.М., Салогуб А.М., Бондарчук В.М., Лобода В.П. Показники довічної продуктивності корів української червоно-рябої молочної породи залежно від методів підбору. Таврійський науковий вісник: Науковий журнал. Херсон: Грінь Д.С., 2015. Вип. 93, С. 191-196.

43. Хмельничий Л.М., Салогуб А.М., Бондарчук В.М., Лобода В.П. Тривалість використання та довічна продуктивність корів залежно від методів підбору та бугаїв-плідників української червоно-рябої молочної породи. Вісник Сумського національного аграрного університету. Серія «Тваринництво», 2015. Вип. 6 (28), С. 65-70.

44. Хмельничий Л.М., Вечорка В. В. Тривалість життя корів українських червоно-рябої та чорно-рябої молочних порід залежно від оцінки лінійних ознак вимені. Вісник Сумського національного аграрного університету. Серія «Тваринництво», 2018. Вип. 7(35), С. 12-18.

45. Хмельничий С.Л. Оцінка екстер'єру тварин сумського внутрішньопородного типу української чорно-рябої молочної породи: дис. ... кандидата с.-г. наук : 06.02.01. Ін-т розведення і генетики тварин НААН. с. Чубинське Київської обл., 2017. $222 \mathrm{c}$.

46. Хмельничий Л. М. Пожизненная продуктивность коров украинской красно-пестрой молочной породы в зависимости от вариантов підбора. Zootehnie şi Biotehnologii agricole materialele Simpozionului Ştiinţific Internaţional „85 ani ai Facultăţi de Agronomie - realizări şi perspective", dedicat aniversării a 85 de ani de la fondarea Universităţi Agrare de Stat din Moldova. Chişinău, 2018. Vol. 52(2), P. 309-314.

47. Эрнст Л.К., Кравченко Н.А., Солдатов А.П. Племенное дело в животноводстве. М. : Агропромиздат, 1987. 287 с.

48. Jovanovac, S., and Raguž N. 2011 Analysis of the relationships between type traits and longevity in Croatian Simmental cattle using survival analysis. Agriculturae Conspectus Scientificus. 76(3): 249-253.

49. Kern, E.L., Cobuci J.A., Costa C.N., McManus C.M., Campos G.S., Almeida T.P., and Campos R.V. 2014. Genetic association between herd survival and linear type traits in Holstein cows under tropical conditions. Italian J. Animal Science.13:3419.

50. Perez-Cabal, M.A., Garcia C., Gonzalez-Recio O., and Alenda R. 2006. Genetic and phenotypic relationships among locomotion type traits, profit, production, longevity, and fertility in Spanish dairy cows. J. Dairy Sci. 89:1776-1783.

51. Sewalem, A., Kistemaker G.J., Miglior F., and Van Doormaal B. J. 2004. Analysis of the relationship between type traits and functional survival in Canadian Holsteins using a Weibull Proportional Hazards Model. J. Dairy Sci. 87:3938-3946.

52. Wright, J.R., Wiggans G.R., Muenzenberger C. J., and Neitzel R. R. 2013. Short communication: Genetic evaluation of mobility for Brown Swiss dairy cattle. J. Dairy Sci. 96: 2657-2660.

53. Zink, V., Zavadilová L., Lassen J., Štípková M., Vacek M., Štolc L. 2014. Analyses of genetic relationships between linear type traits, fat-to-protein ratio, milk production traits, and somatic cell count in first-parity Czech Holstein cows. Czech J. Anim. Sci., 59(12): 539-547.

\section{References:}

1. Burkat, V.P., and Ladyka, V.I., 1996. Do pytannya stvorennya molochnoho typu buroyi khudoby. Udoskonalennya pleminnykh i produktyvnykh yakostey populyatsiyi buroyi khudoby. Materialy naukovo-vyrobnychoyi konferentsiyi 25-27 chervnya 1996 roku. K.: Asotsiatsiya "Ukrayina" [To the question of creating a dairy type of Brown cattle. Improvement of breeding and productive qualities of Brown cattle population. Materials of scientific and production conference June 25-27, 1996]. K.: Association "Ukraine", pp. 3-5.

2. Burkat, V.P., and Polupan, Yu.P., 2004. Rozvedennya tvaryn za liniyamy: henezys ponyat' i metodiv ta suchasnyy selektsiynyy kontekst [The genesis of concepts and methods, and modern selection context: breeding of animals by lines]. K.: Ahrarna nauka, pp. 68.

3. Efimova, L.V., Kulakova, T.V., Ivanova, O.V., and Ivanov, E.A., 2017. Vzaimosvjaz' mezhdu priznakami linejnoj ocenki jekster'era i molochnoj produktivnost'ju korov [The relationship between the traits of linear assessment of the conformation and milk production of cows]. Vestnik Novosibirskogo gosudarstvennogo agrarnogo universiteta, issue 3(44), pp. 115-124.

4. Vinnychuk, D.T. 1982. Struktura porody velykoyi rohatoyi khudoby [Structure breed of cattle]. Visnyk sil's'kohospodars'koyi nauky, issue 8, pp. 33-38. 
5. Voronina, E., Strekozov, N., Ambrampal'skij, F., and Abylkasymov, D., 2007. Vlijanie variantov podbora korov na ih molochnuju produktivnost' [Influence of cow selection options on their dairy productivity]. Molochnoe i mjasnoe skotovodstvo, issue 4, pp. 8-10.

6. Hladiy, M.V., Polupan, Yu.P., Bazyshyna, I.V., Bezrutchenko, I.M., Polupan., N.L., 2014. Vplyv henetychnykh i paratypovykh chynnykiv na hospodars'ky korysni oznaky koriv [Influence of genetic and paratypical factors on economically useful traits of cows]. Rozvedennya i henetyka tvaryn, issue 48, pp. 48-61.

7. Zubets, M.V., Burkat V.P., Mel'nik Yu.F. [i dr.]; pod red. M.V. Zubtsa, V.P. Burkata. 1997. Genetika, selektsiya i biotekhnologiya v skotovodstve [Genetics, Breeding and Biotechnology in cattle breeding]. K.: "BMT".

8. Dymchuk, A.V. 2008. Molochna produktyvnist' koriv podil's'koho zavods'koho typu ukrayins'koyi chorno-ryaboyi molochnoyi porody za riznykh variantiv pidboru [Dairy productivity of cows of Podilsky breed type of Ukrainian Black-and-White Dairy breeds for different variants of selection]. Rozvedennya i henetyka tvaryn : mizhvidomchyy tematychnyy naukovyy zbirnyk. K.: Ahrarna nauka, issue 42, pp. 55-62.

9.Zubets', M.V., and Polupan, Yu.P., 1996. Metody i znachennya ekster"yernoyi otsinky molochnoyi khudoby [Methods and importance of external evaluation of dairy cattle]. Novi metody selektsiyi $i$ vidtvorennya vysokoproduktyvnykh porid $i$ typiv tvaryn: Materialy naukovo-vyrobnychoyi konf., pp. 74-75.

10. Ignat'eva, N.L., 2018. Produktivnye kachestva cherno-pestrogo skota v zavisimosti ot lineynoy prinadlezhnosti [Productive qualities of Black-and-White cattle depending on linear affiliation]. V sbornike: Puti realizatsii Federal'noy nauchno-tekhnicheskoy programmy razvitiya sel'skogo khozyaystva na 2017-2025 gody. Materialy mezhdunarodnoy nauchno-prakticheskoy konferentsii, posvyashchennoy 75-letiyu Kurganskoy oblasti. Pod obshchey redaktsiey S.F. Sukhanovoy, pp. 458-462.

11. Kochuk-Yashchenko, O.A., 2014. Liniyna otsinka typu i molochna produktyvnist' koriv ukrayins'koyi chorno-ryaboyi molochnoyi porody riznoyi liniynoyi nalezhnosti [Linear assessment of the type and milk productivity of cows Ukrainian Black-and-White Dairy breed of different linear affiliation]. Zbirnyk naukovykh prats' Vinnyts'koho NAU, issue 1(83), pp. 139-149.

12. Kochuk-Yashchenko, O.A., 2017. Osoblyvosti ekster"yernoho typu ta molochnoyi produktyvnosti koriv-pervistok ukrayins'koyi chorno-ryaboyi molochnoyi porody za riznykh variantiv pidboru [Features of conformation type and milk productivity of cows-heifers of Ukrainian Black-and-White dairy breed with different variants of selection]. Visnyk Sums'koho NAU. Seriya "Tvarynnytstvo", issue 5/1(31), pp. 90-96.

13. Ladyka, V.I., Khmel'nychyi, L.M., and Salohub, A.M., 2010. Spoluchna minlyvist' statey ekster"yeru koriv z molochnoyu produktyvnistyu [Correlative variability of the conformation type traits in cows with milk productivity]. Zbirnyk naukovykh prats' Bilotserkivs'koho NAU. Tekhnolohiya vyrobnytstva i pererobky produktsiyi tvarynnytstva. Bila Tserkva, issue 3(72), pp. 9-11.

14. Levina, G., Sivkin, N., and Petrova, I., 2002. Pozhiznennyy udoy i dolgoletie korov [Lifetime milk yield and longevity of cows]. Molochnoe i myasnoe skotovodstvo, issue 6, pp. 27-29.

15. Merkur'eva, E.K., 1977. Geneticheskie osnovy selektsii v skotovodstve [Genetic basis of selection in cattle breeding]. Moscov: Kolos.

16. Khmel'nychyi, L.M., Ladyka, V.I., Polupan, Yu.P., and Salohub, A.M., 2008. Metodyka liniynoyi klasyfikatsiyi koriv molochnykh i molochno-m"yasnykh porid za typom [The method of linear classification cows of Dairy and Dairy-Beef breeds by type]. Sumy: "Mriya-1", pp. 28.

17. Moiseev, K.A., Pavlova, T.V., and Kazarovets, N.V., 2012. Vliyanie genotipicheskikh faktorov na prinadlezhnost' khozyaystvennogo ispol'zovaniya i pozhiznennuyu molochnuyu produktivnost' korov v stade RUP "Uchkhoz BGSKhA" [Influence of genotypic factors on the belonging of economic use and lifelong productivity of cows in the herd of RUE "Uchkhoz BGSHA"]. Rozvedennya i henetyka tvaryn, issue 46, pp. 106-109.

18. Khmel'nychyi, L.M., Salohub, A.M., Bondarchuk, V.M., and Shevchenko, A.P., 2015. Molochna produktyvnist' koriv oderzhanykh pry vnutrishn'o liniynomu pidbori ta mizhliniynykh krosakh [Milk productivity of cows obtained within intralinear selection and interlinear crosses]. Naukovo-teoretychnyy zbirnyk Zhytomyrs'koho natsional'noho ahroekolohichnoho universytetu. ZhNAEU, issue 2(52), pp. 51-56.

19. Chernyak, N.H., Honcharuk, O.P., Koziy, V.I., and Chernyak, S.V., 2017. Otsinka buhayiv-plidnykiv za liniynoyu otsinkoyu typu dochok ukrayins'koyi chorno-ryaboyi molochnoyi porody [Estimation of sires according to the linear assessment of the type of daughters of Ukrainian Black-and-White dairy breed]. Visnyk Sums'koho NAU. Seriya "Tvarynnytstvo", issue 5(31), pp. 181-187.

20. Pelekhatyy, M., and Kochuk-Yashchenko, O., 2014. Otsinka molochnoyi produktyvnosti koriv za ekster"yerom [Evaluation of milk productivity cows according to the conformation]. "Tvarynnytstvo Ukrayiny", issue 11, pp. 5-9.

21. Pelekhatyy, M.S., and Kucher, D.M., 2012. Efektyvnist' vykorystannya krosiv liniy v zavods'komu stadi ukrayins'koyi chorno-ryaboyi molochnoyi porody [Efficiency of use of line crosses in the stud flock of Ukrainian Black-and-White dairy breed]. Visn. ZhNAEU, issue 2(31), pp. 141-151.

22. Polupan, Yu.P., 1999. Ekster"yerni osoblyvosti pervistok riznykh porid i poyednan' [Conformation featers of first-calf cows of different breeds and combinations]. Rozvedennya i henetyka tvaryn, issue 30, pp. 10-16.

23. Polupan, Yu.P., 1997. Liniyna otsinka pervistok za typom pry vidtvornomu skhreshchuvanni [Line scoring firstborn cows by the type of reproductive crossbreeding]. Visnyk Bilotserkivs'koho DAU. Bila Tserkva, issue 2(1), pp. 196-200.

24. Polupan, Yu.P., 2000. Otsinka buhayiv za typom dochok [Estimation of sires according to the type of daughters]. Visnyk ahrarnoyi nauky, issue 5, pp. 45-49.

25. Polupan, Yu.P., 2007. Sub"yektyvni aktsenty z deyakykh pytan' henetychnykh osnov selektsiyi ta porodoutvorennya [Subjective accents on some questions of genetic basis of selection and breed formation]. Rozvedennya i henetyka tvaryn, issue 41, pp. 194-208. 
26. Ladyka, V.I., Khmel'nychyi, L.M. Burkat, V.P., and Ruban, S.Yu., 2010. Reyestratsiya ICAR. Dovidnyk [ICAR Registration. Reference book]. Sumy: Sums'kyy Natsional'nyy Ahrarnyy Universytet, pp. 457.

27. Ruban, Yu.D., 2005. Teoriya i praktyka rozvedennya velykoyi rohatoyi khudoby za liniyamy [The theory and practice of cattle breeding along the lines]. Rozvedennya $i$ henetyka tvaryn, issue 38, pp. 91-96.

28. Salohub, A.M., and Khmel'nychyi, L.M., 2010. Osoblyvosti liniynoho rozvedennya v selektsiynomu polipshenni produktyvnosti koriv pleminnoho stada [Features linear breeding in selection improvement productivity of cows pedigree herd]. Zbirnyk naukovykh prats' Vinnyts'koho NAU. Seriya: Sil's'kohospodars'ki nauky, issue 5, pp. 129-133.

29. Salohub, A.M., and Khmel'nychyi, L.M., 2011. Osoblyvosti uspadkovuvanosti ta spoluchnoyi minlyvosti oznak ekster"yeru koriv ukrayins'koyi chervono-ryaboyi molochnoyi porody [Features of heritability and correlative variability conformation traits of cows Ukrainian Red-and-White Dairy breed]. Zbirnyk naukovykh prats' Vinnyts'koho NAU. Seriya: Sil's'kohospodars'ki nauky, issue 8(48), pp. 59-62.

30. Hopka, B.M., Kovalenko, V.P., Mel'nyk, Yu.F., Naydenko, K.A., Nezhlukchenko, T.I., Pelykh, V.H., Rudyk, I.A., Sakhats'kyy, M.I., Trofymenko, O.L., Uhnivenko, A.M., Tsytsyurs'kyy, L.M., Sheremeta, V.I. Za zah. red. Mel'nyka, Yu.F. Kovalenka, V.P. ta Uhnivenka, A.M. 2007. Selektsiya sil's'kohospodars'kykh tvaryn, pp. 554.

31. Khmel'nychyi, L.M., Salohub, A.M., Khmel'nychyy, S.L., and Loboda, A.V., 2018. Spivvidnosna minlyvist' ta uspadkovuvanist' liniynykh oznak ekster"yeru koriv sums'koho vnutrishn'oporodnoho typu ukrayins'koyi chorno-ryaboyi molochnoyi porody [Correlative variability and heritability of linear traits conformation cows of Sumy intrabreed type of Ukrainian Black-and-White dairy breed]. Visnyk Sums'koho natsional'noho ahrarnoho universytetu. Seriya :"Tvarynnytstvo", issue 2(34), pp. 92-96.

32. Stavets'ka, R.V., and Rudyk, I.A., 2010. Dynamika rozvytku liniy molochnoyi khudoby [Dairy livestock lines dynamics of development]. Zbirnyk naukovykh prats'. Seriya "Tekhnolohiya vyrobnytstva i pererobky produktsiyi tvarynnytstva". Kam"yanets'Podil's'kyy, issue 18, pp. 197-200.

33. Usova, T., 1999. Sochetaemost' genealogicheskikh grupp i liniy u ayrshirskogo skota [Compatibility of genealogical groups and lines in Ayrshire cattle]. Molochnoe i myasnoe skotovodstvo, issue 7, pp. 21-23.

34. Khmel'nychyi, L.M., and Vechorka, V.V., 2018. Vplyv spadkovykh chynnykiv na ekster"yernyy typ koriv ukrayins'koyi chorno-ryaboyi molochnoyi porody [Influence of hereditary factors on the conformation type of Ukrainian Black-and-White dairy breed]. Rozvedennya ta selektsiya tvaryn: dosyahnennya, problemy, perspektyvy: zbirnyk naukovykh prats' mizhnar. nauk.-prakt. konf., 20 kvitnya 2018 r. Zhytomyr: Polissya, pp. 105-110.

35. Khmel'nychyi, L.M., and Salohub, A.M., 2012. Efektyvnist' poyednannya henealohichnykh formuvan' v selektsiyi molochnoyi khudoby [Effectiveness of the combination of genealogical formations in the dairy cattle selection]. Zbirnyk naukovykh prats' Podil's'koho derzh. ahrarno-tekhnichnoho universytetu. Seriya "Tekhnolohiya vyrobnytstva i pererobky produktsiyi tvarynnytstva". Kam"yanets'-Podil's'kyy, issue 20, pp. 285-287.

36. Khmel'nychyi, L.M., and Loboda, V.P., 2013. Selektsiyne znachennya liniy ta buhayiv-plidnykiv u formuvanni oznak molochnoyi produktyvnosti yikhn'oho potomstva [The breeding value of lines and sires in the formation traits of milk production of their progeny]. Visnyk Zhytomyrs'koho natsional'noho ahroekolohichnoho universytetu. Zhytomyr, issue 1/2(35), pp. 40-45.

37. Khmel'nychyi, L.M. 2017. Efektyvnist' vykorystannya metodyky liniynoyi klasyfikatsiyi dlya otsinky buhayiv-plidnykiv za ekster"yernym typom yikhnikh dochok u stadi z rozvedennya ukrayins'koyi chervono-ryaboyi molochnoyi porody [The effectiveness of using linear classification method for estimation of sires according to the conformation type daughters in the herd for breeding of Ukrainian Red-and-White dairy breed]. Visnyk Sums'koho NAU. Seriya "Tvarynnytstvo", issue 7(33), pp. 17-24.

38. Khmel'nychyi, L.M., and Vechorka, V.V., 2010. Efektyvnist' vnutrishn'o liniynoho rozvedennya ta poyednuvanosti liniy v selektsiyi holshtyns'koyi khudoby [Efficiency of intra-linear breeding and combining lines in Holstein cattle selection]. Visnyk Sums'koho NAU. Nauk. zhurnal. Seriya "Tvarynnytstvo", issue (18), pp. 149-153.

39. Khmel'nychyi, L.M., and Vechorka, V.V., 2016. Efektyvnist' vplyvu henealohichnykh formuvan' na pokaznyky dovholittya ta dovichnoyi produktyvnosti koriv ukrayins'koyi chervono-ryaboyi molochnoyi porody [Effectiveness of genealogical formations influencing on the indicators of longevity and lifetime productivity cows of Ukrainian Red-and-White dairy breed]. Visnyk Sums'koho NAU. Seriya "Tvarynnytstvo", issue 1(29), pp. 3-10.

40. Khmel'nychyi, L.M., and Suprun, I.O., 2010. Otsinka koriv-pervistok ukrayins'kykh chervono- ta chorno-ryaboyi molochnykh porid za yemnistyu vymeni [Estimation of the first-calf cows of Ukrainian Red and Black-and-White dairy breeds by udder capacity]. Zbirnyk naukovykh prats' Luhans'koho NAU. Seriya "Sil's'kohospodars'ki nauky". Luhans'k. "Elton-2", issue 21, pp. 187188.

41. Khmel'nychyi, L. M., and Vechorka, V.V., 2014. Otsinka potomstva liniy ta buhayiv-plidnykiv holshtyns'koyi porody kanads'koyi selektsiyi za oznakamy dovichnoyi produktyvnosti [Estimation of progeny lines and sires of Holstein breed Canadian breeding by traits of lifetime productivity]. Naukovyy visnyk natsional'noho universytetu bioresursiv i pryrodokorystuvannya Ukrayiny. Seriya: Tekhnolohiya vyrobnytstva i pererobky produktsiyi tvarynnytstva, issue 202, pp. 83-90.

42. Khmel'nychyi, L.M., Salohub, A.M., Bondarchuk, V.M., and Loboda, V.P., 2015. Pokaznyky dovichnoyi produktyvnosti koriv ukrayins'koyi chervono-ryaboyi molochnoyi porody zalezhno vid metodiv pidboru [Indicators of lifetime productivity of cows Ukrainian Red-and-White dairy breed depending on the methods of selection]. Tavriys'kyy naukovyy visnyk: Naukovyy zhurnal. Kherson : Grin' D.S., issue 93, pp. 191-196.

43. Khmel'nychyi, L.M., Salohub, A.M., Bondarchuk, V.M., and Loboda, V.P., 2015. Tryvalist' vykorystannya ta dovichna produktyvnist' koriv zalezhno vid metodiv pidboru ta buhayiv-plidnykiv ukrayins'koyi chervono-ryaboyi molochnoyi porody [Duration of use and lifetime productivity of cows depending on the methods of selection and sires of Ukrainian Red-and-White dairy breed]. Visnyk Sums'koho natsional'noho ahrarnoho universytetu. Seriya "Tvarynnytstvo", issue 6(28), pp. 65-70.

Вісник Сумського національного аграрного університету 
44. Khmel'nychyi, L.M., and Vechorka, V.V., 2018. Tryvalist' zhyttya koriv ukrayins'kykh chervono-ryaboyi ta chorno-ryaboyi molochnykh porid zalezhno vid otsinky liniynykh oznak vymeni [Longevity of cows Ukrainian Red-and-White and Black-and-White Dairy breeds depending on estimates of linear udder traits]. Visnyk Sums'koho natsional'noho ahrarnoho universytetu. Seriya "Tvarynnytstvo", issue 7(35), pp. 12-18.

45. Khmel'nychyi, S.L., 2017. Otsinka ekster"yeru tvaryn sums'koho vnutrishn'oporodnoho typu ukrayins'koyi chorno-ryaboyi molochnoyi porody: dys. ... kandydata s.-h. nauk : 06.02.01. In-t rozvedennya i henetyky tvaryn NAAN. s. Chubyns'ke Kyyivs'koyi obl. - Estimation of the conformation of animals of Sumy intrabreed type of Ukrainian Black-and-White dairy breeds: Dis. ... candidate of agricultural Sciences: 06.02.01 Institute of Animal Breeding and Genetics NAAS. v. Chubinskoe, Kiev region, 222.

46. Khmel'nichyi, L. M. 2018. Pozhiznennaya produktivnost' korov ukrainskoy krasno-pestroy molochnoy porody v zavisimosti ot variantov podbora - Lifetime productivity of Ukrainian Red-and-White dairy cows, depending on the selection variants. Zootehnie şi Biotehnologii agricole materiale le Simpozionului Ştiinţific Internaţional „85 ani ai Facultăţii de Agronomie - realizări şi perspective”, dedicate aniversăriia 85 de ani dela fondarea Universităţii Agrarede Stat din Moldova. Chişinău. 52(2):309-314.

47. Ernst, L.K., Kravchenko, N.A., and Soldatov, A.P.,1987. Plemennoe delo v zhivotnovodstve [Breeding business in animal husbandry]. M.: Agropromizdat.

48. Jovanovac, S., and Raguž N., 2011 Analysis of the relationships between type traits and longevity in Croatian Simmental cattle using survival analysis. Agriculturae Conspectus Scientificus. 76(3): 249-253.

49. Kern, E.L., Cobuci, J.A., Costa, C.N., McManus, C.M, Campos, G.S., Almeida, T.P., and Campos R.V., 2014. Genetic association between herd survival and linear type traits in Holstein cows under tropical conditions. Italian J. Animal Science.13:3419.

50. Perez-Cabal, M. A., Garcia C., Gonzalez-Recio O., and Alenda R., 2006. Genetic and phenotypic relationships among locomotion type traits, profit, production, longevity, and fertility in Spanish dairy cows. J. Dairy Sci. 89:1776-1783.

51. Sewalem, A., Kistemaker G.J., Miglior F., and VanDoormaal B.J., 2004. Analysis of the Relationship Between Type Traits and Functional Survival in Canadian Holsteins Using a Weibull Proportional Hazards Model. J. Dairy Sci. 87:3938-3946.

52. Wright, J.R., Wiggans, G.R., Muenzenberger, C.J., and Neitzel, R.R., 2013. Short communication: Genetic evaluation of mobility for Brown Swiss dairy cattle. J. Dairy Sci. 96: 2657-2660.

53. Zink, V., Zavadilová L., Lassen J., Štípková M., Vacek M., Štolc L., 2014. Analyses of genetic relationships between linear type traits, fat-to-protein ratio, milk production traits, and somatic cell count in first-parity Czech Holstein cows. Czech J. Anim. Sci., 59(12): 539-547.

\begin{abstract}
Khmelnychyi, L.M., Bondarchuk, L.V.

Variability of linear conformation traits of the first-calf cows of Sumy intrabreed type of the Ukrainian Black-andWhite dairy breed by different variants of selection of genealogical formations.

In the aspect of research on cow's consolidation of Sumy intrabreed type of Ukrainian Black-and-White dairy by conformation, an estimation of first-calf cows was carried out using the linear classification method. The urgency of question was to study the influence on the conformation of cow methods of selection of sires using various combinations of genealogical formations. According to the results of the linear classification of sires' offspring of Valiant's parent line, there was a significant variability in the estimates of group traits within estimated combinations with maternal lines. The best-in-class of conformation traits characterizing the dairy type revealed the progeny of the first-calf cows received from intra-linear selection (84.2 scores) and cross lines of Valiant $x$ S.T. Rokita (84.3 scores) and Valiant $\times$ Kheneve (84.0 scores). The worst traits of dairy type were expressed in first-calf cows, obtained as a result of cross lines of Valiant $\times$ Metta (82.2 scores), which with a significant difference inferior to peers obtained in the variants of intra-linear and interlinear selection, respectively on 2.0 and $1.1-2.1$ scores $(P<0.05-0.001)$. The variability of estimates of the first-calf cows by group traits and final assessment in the variants of various linear combinations of the Matt's parent line with maternal Valiant, S.T. Rokita, Monfrech, Kheneve and Sjuprim differed significantly from each other and, in particular, from the level of offspring estimates obtained from internally - and interlinear selection of Holstein sires parental lines of Valiant with maternal Valiant, S.T. Rokita and Kheneve. In general, the best results in the system of 100-point evaluation by group traits and the final assessment of type were found in the variant of intra-linear selection of Valiant line and at its cross with maternal lines, the continuators of which were sires of Holstein breed. According to the assessment of descriptive traits, significant variability has been determined both within the groups of first-calf cows obtained from different interlinear combinations and within each estimated group. The best indicators of estimates of descriptive traits had cows in the selection variants which used sires of Holstein breed from the parent and maternal side.
\end{abstract}

Key words: first-calf cows, Ukrainian Black-and-White dairy breed, conformation type, sires, cross lines.

Дата надходження до редакції: 19.07.2019 р. 